IZA DP No. 5097

Outsourcing Cost and Tax Progression under Nash Wage Bargaining with Flexible Outsourcing

Erkki Koskela

July 2010 


\title{
Outsourcing Cost and Tax Progression under Nash Wage Bargaining with Flexible Outsourcing
}

\author{
Erkki Koskela \\ University of Helsinki \\ and IZA
}

\author{
Discussion Paper No. 5097 \\ July 2010 \\ IZA \\ P.O. Box 7240 \\ 53072 Bonn \\ Germany
}

Phone: +49-228-3894-0

Fax: +49-228-3894-180

E-mail: iza@iza.org

Any opinions expressed here are those of the author(s) and not those of IZA. Research published in this series may include views on policy, but the institute itself takes no institutional policy positions.

The Institute for the Study of Labor (IZA) in Bonn is a local and virtual international research center and a place of communication between science, politics and business. IZA is an independent nonprofit organization supported by Deutsche Post Foundation. The center is associated with the University of Bonn and offers a stimulating research environment through its international network, workshops and conferences, data service, project support, research visits and doctoral program. IZA engages in (i) original and internationally competitive research in all fields of labor economics, (ii) development of policy concepts, and (iii) dissemination of research results and concepts to the interested public.

IZA Discussion Papers often represent preliminary work and are circulated to encourage discussion. Citation of such a paper should account for its provisional character. A revised version may be available directly from the author. 
IZA Discussion Paper No. 5097

July 2010

\section{ABSTRACT}

\section{Outsourcing Cost and Tax Progression under Nash Wage Bargaining with Flexible Outsourcing}

It is analyzed the impacts of outsourcing cost and wage tax progression under labor market imperfections with Nash wage bargaining and flexible outsourcing. With sufficiently strong (weak) labor market imperfection, lower outsourcing cost has a wage-moderating (wageincreasing) effect so that there is a negative (positive) effect on equilibrium unemployment. Higher tax progression, to keep the relative tax burden per worker constant, has a wage moderating and a positive effect on employment and negative effect on outsourcing.

JEL Classification: H22, J41, J51

Keywords: Nash wage bargaining, outsourcing, labor tax reform

Corresponding author:

Erkki Koskela

Department of Economics

University of Helsinki

P.O. Box 17 (Arkadiankatu 7)

00014 Helsinki

Finland

E-mail: erkki.koskela@helsinki.fi

\footnotetext{
* I thank the Academy of Finland (grant No. 1217622) for financial support.
} 


\section{Introduction}

Wage differences across countries constitute an important explanation for the currently significant business practice of international outsourcing. ${ }^{1}$ Outsourcing can take two alternative forms. Firms may write long-term contracts that fix the amount of outsourcing before the trade union sets the wage, or alternatively firms may be flexible enough later on to decide upon the amount of outsourcing activity after the domestic wage is set by the trade union.

In the presence of flexible outsourcing it is analyzed the following questions: ${ }^{2}$ What are the effects of the outsourcing costs and the wage tax rate and the tax exemption on the Nash wage formation under labor market imperfections with substitutability between outsourcing and domestic labor? What are the effects of the labor tax reform, to keep the relative tax burden per worker constant, on domestic wage setting, employment and outsourcing? ${ }^{3}$ With flexible outsourcing the wage elasticity of domestic labor demand is an increasing function of the lower outsourcing cost and of higher wage rate of domestic labor. With sufficiently strong (weak) labor market imperfections a lower outsourcing cost has a wage-moderating (wage-increasing) effect so that there is a negative (positive) effect on equilibrium unemployment. The wage tax rate has a positive effect and the tax exemption a negative effect on the wage negotiation. Higher tax progression under Nash wage bargaining, to keep the relative tax burden per worker constant, has a wage-moderating effect and a positive effect on domestic employment and a negative effect on outsourcing.

Section II presents the basic structure of theoretical framework and domestic labor demand and outsourcing are studied in section III. Wage determination and equilibrium unemployment are presented in section IV under linearly progressive wage

$1 \quad$ Amiti and Wei (2005) emphasize the big difference on labor costs as the main explanation for the strong increase in outsourcing of both manufacturing and services to countries with low labor costs.

2 Skaksen (2004) has analyzed in the absence of taxation the implications of outsourcing for wage setting and employment under imperfectly competitive labor markets in terms of both potential (non-realized) and realized international outsourcing for wage setting and employment by assuming that the firms do not commit themselves to outsourcing prior wage negotiation. This has been analyzed in the absence of outsourcing, see e.g. Koskela and Vilmunen (1996). 
tax. The effects of labor tax progression on wage setting, employment and outsourcing are analyzed in section V and conclusions in section VI.

\section{Basic Framework}

At stage 1 the government as a Stackelberg leader fixes labor tax parameters. The government employs a wage tax rate $t$, which is levied on the wage $w$, minus a tax exemption $a$. The tax base per worker for $t$ equals $(w-a)$ and the marginal tax rate $t$ exceeds the average tax rate $t(1-a / w)$ so that the tax system is linearly progressive. ${ }^{4}$ The net-of-tax wage, the worker receives, is given by $w^{n}=w(1-t)+t a$. At stage 2 the labor union and the firm negotiate wage formation by taking tax parameters as given and anticipating the domestic labor demand and outsourcing. At stage 3 both the domestic labor demand and the outsourcing is decided by the firm by taking tax parameters and wage setting as given.

To derive an explicit solution a decreasing returns to scale production function is presented as

$$
R(L, M)=\frac{\delta}{\delta-1}(L+\gamma M)^{\frac{\delta-1}{\delta}}, \quad \delta>1, \gamma>0
$$

where $L$ is the amount of domestic labor and $M$ denotes the firm's labor input acquired from external suppliers through outsourcing. The parameter $\delta>1$ means that the production function is a concave function of domestic labor and outsourcing inputs. ${ }^{5}$ According to (1) domestic labor and outsourcing are substitutes and the parameter $\gamma>0$ captures the productivity of outsourcing relative to labor.

\section{Domestic Labor Demand and Outsourcing}

For about tax progression, see e.g. Lambert (2001, chapters 7-8.

Lommerud et el. (2006) in the absence of taxation have demonstrated how international mergers might curb the market power of unions giving socially excessive incentive for international mergers, unless products are close substitutes. This paper does not focus on the simultaneous presence of imperfections in labor and product markets. 
Under flexible outsourcing the firm decides simultaneously on domestic employment $L$ and outsourcing $M$ so as to maximize the profit function the output price is normalized to unity

$$
\underbrace{\operatorname{Max}}_{L, M} \pi=\frac{\delta}{\delta-1}(L+\gamma M)^{\frac{\delta-1}{\delta}}-w L-C(M),
$$

by taking the negotiated wage and the cost of outsourcing as given, where $C(M)=0,5 c M^{2}$ is a convex cost of establishing capacity $M$ for foreign outsourced. This outsourcing labor input captures the idea that exploitation of the marginal cost advantages associated with production in low-wage countries typically requires that the firm makes irreversible investment into the establishment of network of supplies in the relevant low-wage countries. The first-order conditions are $\pi_{L}=(L+\gamma M)^{-\frac{1}{\delta}}-w=0$, and $\pi_{M}=(L+\gamma M)^{-\frac{1}{\delta}} \gamma-c M=0$, which give the labor demand and outsourcing

$$
\begin{aligned}
& L=w^{-\delta}-\gamma M=w^{-\delta}-\gamma^{2} \frac{w}{c}, \\
& M=\gamma \frac{w}{c} .
\end{aligned}
$$

Domestic labor demand is a negative function of wage rate and productivity of outsourcing, and a positive function of cost of outsourcing, while outsourcing is a positive function of wage rate and productivity of outsourcing and a negative function of cost of outsourcing. In this model the outsourcing elasticities are constant, while the wage elasticity of labor demand is not constant

$$
\eta(w, c, \gamma) \equiv-\frac{L_{w} w}{L}=\frac{\delta w^{-\delta}+\gamma^{2} \frac{w}{c}}{L}=\delta\left(1+\gamma \frac{M^{*}}{L^{*}}\right)+\gamma \frac{M^{*}}{L^{*}}=\delta+(1+\delta) \gamma \frac{M^{*}}{L^{*}} .
$$

The relationship between the wage rate (the outsourcing cost) and the wage elasticity of domestic labor demand is positive (negative), i.e. $\eta_{w}=(1+\eta)(1+\delta) \gamma \frac{M^{*}}{w L^{*}}>0$ and $\eta_{c}=-(1+\delta) \gamma \frac{M^{*}}{c L^{*}}\left(1+\gamma \frac{M^{*}}{L^{*}}\right)<0$. Higher wage rate and lower outsourcing cost increasing the wage elasticity of domestic labor demand lies in conformity with 
empirical evidence. ${ }^{6}$ Also the productivity of outsourcing will have a positive effect on the wage elasticity of domestic labor demand, i.e. $\eta_{\gamma}>0$.

\section{Wage Determination via Nash Bargaining under Linearly Progressive Wage Tax}

This section investigates wage determination by applying the Nash bargaining following the right-to-manage approach. The labor union's objective function in the presence of linearly progressive wage taxation is assumed to be $\hat{U}=(w(1-t)+t a) L^{*}+b\left(N-L^{*}\right)$ under the wage tax rate $t$ and the tax exemption $a$ and $L^{*}$ denotes the total domestic employment. $b$ is the outside option available to union members and $N$ is the number of union members $\left(N \geq L^{*}\right)$ and the threat point is $U^{o}=N b$ so that the relevant target function of the labor union is $U=\hat{U}-N b=L^{*}(w(1-t)+t a-b)$. The firm and the labor union negotiate wage rate to solve the following optimization problem

$$
\begin{gathered}
\underbrace{\operatorname{Max}}_{w} \Omega=\left[L^{*}(w(1-t)+t a-b)\right]^{\beta}\left[R\left(L^{*}, M^{*}\right)-w L^{*}-0,5 M^{* 2}\right]^{1-\beta} \\
\text { s.t. } L^{*}=w^{-\delta}-\gamma^{2} \frac{w}{c},
\end{gathered}
$$

where the relative bargaining power of the labor union (the firm) is $\beta(1-\beta)$. The first-order condition for the negotiated wage rate can be written as

$$
\Omega_{w}=0 \Leftrightarrow \beta \frac{U_{w}}{U}+(1-\beta) \frac{\pi_{w}^{*}}{\pi^{*}}=0,
$$

where

$$
\frac{U_{w}}{U}=\frac{1}{w}\left[\frac{w(1-\eta(w, c, \gamma))(1-t)+\eta(w, c, \gamma)(b-t a)}{w(1-t)-(b-t a)}\right]>0,
$$

and

\footnotetext{
See e.g. Slaughter (2001) and Hasan et al. (2007).
} 


$$
\frac{\pi_{w}^{*}}{\pi^{*}}=-\frac{1}{w} \frac{w L}{\pi}=-\frac{1}{w} \frac{R_{L} L}{\left[R-R_{L} L-\frac{1}{2} R_{M} M\right]}=-\frac{1}{w} \frac{2(\delta-1)}{[2-\delta+\eta]}<0 .
$$

Substituting (7a) and (7b) into the first-order condition (6) gives the following Nash bargaining solution for the negotiated wage

$$
w^{N}=\frac{\beta \eta(2-\delta+\eta)+(1-\beta) 2(\delta-1)}{\beta(\eta-1)(2-\delta+\eta)+(1-\beta) 2(\delta-1)} \hat{b}=A \hat{b}
$$

where $\eta(w, c, \gamma)$, the outside option is $\hat{b}=\frac{b-t a}{1-t}$ and the mark-up $A>1$ as $1 \geq \beta>0$. Equation (8) is not an explicit form for the wage rate under outsourcing because the mark-up depends in a non-linear way on the wage ratio via the ratio between outsourcing and domestic labor demand. Before initiating a detailed analysis of the relationship we report the negotiated wage for the two special cases with all the bargaining power concentrated into the hands of the labor union or the firm, respectively. In the case of a monopoly labor union $(\beta=1)$ the wage is also determined in implicit form according to

$$
\left.w^{N}\right|_{\beta=1}=\frac{\eta(2-\delta+\eta)}{(\eta-1)(2-\delta+\eta)} \hat{b}=\frac{\eta(w, c, \gamma)}{\eta(w, c, \gamma)-1} \hat{b}
$$

If the firm has all the bargaining power the mark-up factor is reduced to one according to

$$
\left.w^{N}\right|_{\beta=0}=\hat{b} \text {. }
$$

By differentiating the negotiated wage (8) with respect to the outsourcing cost $c$ gives (see Appendix A)

$$
\frac{d w^{N}}{d c}=\frac{\frac{A_{c} w}{A}}{1-\frac{A_{w} w}{A}}
$$


where $1-\frac{A_{w} w}{A}>0$ and $\frac{A_{c} w}{A}\left\{\begin{array}{l}> \\ = \\ <\end{array}\right\} 0$ if $\beta\left\{=\left\{\begin{array}{l}> \\ <\end{array} \frac{2(\delta-1)}{\left(2+(1+\delta) \gamma \frac{M^{*}}{L^{*}}\right)^{2}+2(\delta-1)}\right.\right.$. According to (9) the lower outsourcing cost can decrease wage setting if the relative bargaining power of labor union is higher than the low threshold. This threshold is inversely related to the wage elasticity. Lower outsourcing cost increases the wage elasticity of domestic labor demand by decreasing the mark-up. This is the dominant effect as long as the labor union has a sufficiently strong bargaining power. Also wage is affected by the negative effect on profit according to (7b) and when the labor union has a sufficiently low bargaining power, higher outsourcing due to lower outsourcing cost moderates the profit reducing effect of a higher wage. In this case more outsourcing induces an increase in the wage when the bargaining power lies with the firm to a sufficient degree. ${ }^{7}$

In terms of the wage tax rate and the tax exemption differentiating (8) gives

$$
\frac{d w^{N}}{d t}=\frac{A}{\left(1-\frac{A_{w} w}{A}\right)} \frac{b-a}{(1-t)^{2}}>0 \text { as } b-a>0 \text { and } \frac{d w^{N}}{d a}=-\frac{A}{\left(1-\frac{A_{w} w}{A}\right)} \frac{t}{(1-t)}<0
$$

These results can be summarized in

Proposition 1: In the presence of flexible outsourcing with sufficiently strong (weak) labor market imperfections a lower outsourcing cost has a wagemoderating (wage-increasing) effect so that with a monopoly labor union, a lower outsourcing cost moderates wages. The wage tax rate (tax exemption) has a positive (negative) effect on wage negotiation.

We now analyze the effect of outsourcing cost given labor tax parameters on equilibrium unemployment. According to (8) the wage formation for workers is of the form $w^{N}=A \hat{b}$, where $\hat{b}=\frac{b-t a}{1-t}$ contains the outside option and the linearly 
progressive wage taxation parameters and the mark-up factor is $A>1$. In a general equilibrium the term $b$ should be re-interpreted as the endogenous outside option. By assuming that the taxation is linearly progressive both in the presence of getting employment and in the case of not getting employment but unemployment benefit, which we specify as

$$
b=(1-u)\left(w^{N}(1-t)+t a\right)+u(\bar{b}(1-t)+t a)
$$

where $u$ is the unemployment rate, $\bar{b}$ captures the unemployment benefit and $w$ denotes the wage formation in identical industries (see, e.g. Nickell and Layard (1999), p. 3048-3049 for a further discussion). Assuming a constant benefit-replacement ratio $0<q=\bar{b} / w^{N}<1$ equation (11) can be expressed as

$$
\begin{aligned}
& b=(1-u)\left(w^{N}(1-t)+t a\right)+u\left(q w^{N}(1-t)+t a\right)= \\
& w^{N}(1-t)+t a+u(q-1) w^{N}(1-t)
\end{aligned}
$$

Under this assumption we have $\hat{b}=\frac{b-t a}{1-t}=w^{N}+u(q-1) w^{N}$ and $w^{N}=A \hat{b}$ can be written in terms of endogenous outside option as $w^{N}=A\left[w^{N}+u(q-1) w^{N}\right]$ so that the equilibrium unskilled unemployment can be presented

$$
u=\frac{1}{(1-q)}\left(1-\frac{1}{A}\right)
$$

In terms of outsourcing cost we have as for the impact of outsourcing cost on equilibrium unemployment we initially observe from (13) that $\frac{d u}{d c}=\frac{1}{1-q} \frac{A_{c}}{A^{2}}$.

Combining this observation with (9) we can draw the conclusion that

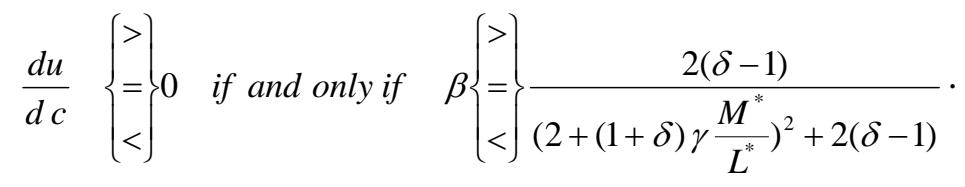


This result can be summarized in

Proposition 2: In the presence of flexible outsourcing with sufficiently strong (weak) labor market imperfections a lower outsourcing cost has a negative (positive) effect on equilibrium unemployment so that with a monopoly labor union, a lower outsourcing cost moderates wages and equilibrium unemployment.

\section{Effects of Labor Tax Progression Policy on Wage Negotiation, Employment and Outsourcing}

Now the analysis concentrates on the effects of tax progression for wage formation and employment by looking as the tax reform that increases tax progression while keeping the average tax burden per worker constant so that

$$
t-\frac{t a}{w}=t^{a}
$$

is constant. The average tax rate progression ( $A R P$ ) is given by the difference between the marginal tax rate $t$ and the average tax rate $t^{a}, A R P \equiv t-t^{a}$. The tax system is progressive if $A R P$ is positive and progression is increased if $A R P$ increases. Government raises the degree of tax progression by increasing $t$ and adjusts $a$ upwards such that $t^{a}$ remains constant. In this analysis the fully-balanced public sector budget aspect is not considered, because only some sectors may engage outsourcing, but not the whole economy.

First the analysis focuses the wage effect of this tax reform under Nash domestic wage bargaining. Differentiating (15) with respect to $t, a$ and $w$ to keep it constant gives $d a=\frac{(w-a)}{t} d t+\frac{a}{w} d w$ and the total wage effect is $d w=w_{t} d t+w_{a} d a$. Substituting the RHS of $d a=\frac{(w-a)}{t} d t+\frac{a}{w} d w$ for $d a$ in $d w=w_{t} d t+w_{a} d a$ gives

$$
\left.\frac{d w^{N}}{d t}\right|_{d t^{a}=0}=\frac{\left(w_{t}+\frac{(w-a)}{t} w_{a}\right)}{\left(1-\frac{w_{a} a}{w}\right)}<0
$$


where $\left(1-\frac{w_{a} a}{w}\right)>0$ and $\left(w_{t}+\frac{(w-a)}{t} w_{a}\right)=-\frac{A}{\left(1-\frac{A_{w} w}{A}\right)} \frac{[w(1-t)+t a-b]}{(1-t)^{2}}<0$.

A higher degree of tax progression, keeping the relative tax burden per worker constant, will decrease the wage rate in the presence of flexible outsourcing. The employment and outsourcing effects of this labor tax reform by using equations (3a), (3b), (16) are

$$
\left.\frac{d L^{*}}{d t}\right|_{d t^{a}=0}=\left.L_{w}^{*} \frac{d w^{N}}{d t}\right|_{d t^{a}=0}>0 \text { and }\left.\frac{d M^{*}}{d t}\right|_{d t^{a}=0}=\left.M_{w}^{*} \frac{d w^{N}}{d t}\right|_{d t^{a}=0}<0
$$

The wage moderating effect of tax progression, to keep the relative tax burden per worker constant, increases domestic labor demand and decreases outsourcing in the presence of flexible outsourcing. ${ }^{8}$ These results can be summarized in

Proposition 3: In the presence of flexible outsourcing increasing the degree of tax progression under Nash wage bargaining, to keep the relative tax burden per worker constant, has a wage-moderating effect, a positive effect on domestic employment and a negative effect on outsourcing.

\section{Conclusions}

This paper has presented the following things in the case of homogenous domestic labor demand with the presence of flexible outsourcing: What are the effects of outsourcing costs on wage formation in an imperfectly competitive labor market under Nash wage bargaining? What are the effects of one labor tax reform on domestic wage setting and domestic employment as well as on outsourcing under flexible outsourcing? It has been shown that with sufficiently strong (weak) labor market imperfections a lower outsourcing cost has a wage-moderating (wage-increasing) effect so that there is a negative (positive) effect on equilibrium unemployment. Increasing

8 Under the monopoly labor union $\left.A\right|_{\beta=1}=\frac{\eta}{\eta-1}$ the qualitative results (16), (17) are similar (see e.g. Koskela and Schöb (2008)). 
the degree of tax progression under Nash wage bargaining, to keep the relative tax burden per worker constant, has a wage-moderating effect and a positive effect of domestic employment and a negative effect on outsourcing.

\section{References:}

Amiti, M. and S.-J. Wei (2005): Fear of Service Outsourcing: Is It Justified?, Economic Policy, April, 307-347.

Hasan, R., D. Mitra and R.V. Ramaswamy (2007): Trade Reforms, Labor Regulations, and Labor Demand Elasticities: Empirical Evidence from India, the Review of Economics and Statistics, 89, 466-481.

Koskela, E. and J. Vilmunen (1996): Tax Progression is Good for Employment in Popular Models of Trade Union Behaviour, Labour Economics, 3, 65-80.

Koskela, E. and R. Schöb (2008): Outsourcing of Unionized Firms and the Impact of Labour Market Policy Reforms, CESifo Working Paper No. 2360, Forthcoming in: Review of International Economics.

Koskela, E. and R. Stenbacka (2009): Equilibrium Unemployment with Outsourcing under Labour Market Imperfections, Labour Economics, 16, 284-290.

Lambert, P.J. (2001): The Distribution and Redistribution of Income, $3^{\text {rd }}$ edition, Manchester University Press.

Lommerud, K.E., F. Meland and L. Sorgard (2006): National versus International Mergers in Unionized Oligopoly, the Rand Journal of Economics, 37, 212-233.

Nickell, S. and R. Layard (1999): Labor Market Institutions and Economic Performance, in Ashelfelter, O., Card, D. (eds): Handbook of Labor Economics, Volume 3C, 3029-3084.

Skaksen, J.R. (2004): International Outsourcing When Labour Markets are Unionized, Canadian Journal of Economics, 37(1), 78-94.

Slaugher, M. (2001): International Trade and Labor Demand Elasticities, Journal of International Economics, 54, 27-56.

\section{Appendix A: Nash wage bargaining and outsourcing cost}

Differentiation of (8) with respect to $w$ and $c$ and substituting $\hat{b}=w / A$ for $\hat{b}$ gives 


$$
\frac{d w^{N}}{d c}=\frac{A_{c} w}{A} /\left(1-\frac{A_{w} w}{A}\right)
$$

Using $\quad X=\beta(\eta-1) Z+(1-\beta) 2(\delta-1), \quad Z=2+(1+\delta) \gamma \frac{M^{*}}{L^{*}}, \quad$ and $\quad$ differentiating $A=\frac{X+\beta Z}{X}$ with respect to $c\left(Z_{c}=\eta_{c}<0\right)$ gives $A_{c}=\frac{-\beta \eta_{c}\left(\beta\left[Z^{2}+2(\delta-1)\right]-2(\delta-1)\right)}{X^{2}} \quad$ so that

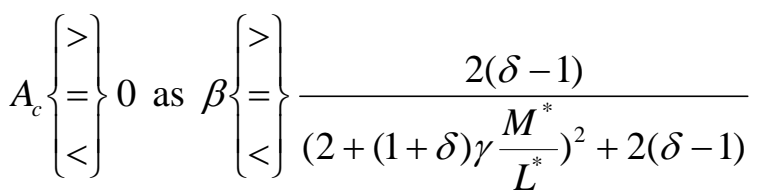

Differentiating the mark-up with respect to the wage $\left(Z_{w}=\eta_{w}>0\right)$ gives

$$
A_{w}=\frac{-\beta \eta_{w}\left(\beta\left[Z^{2}+2(\delta-1)\right]-2(\delta-1)\right)}{X^{2}}
$$

By using (A3) and (A4) equation (A1) can be expressed as

$$
\frac{d w^{N}}{d c}=\frac{\frac{A_{c} w}{A}}{1-\frac{A_{w} w}{A}}=\frac{-\beta \eta_{c} w\left(\beta\left[Z^{2}+2(\delta-1)\right]-2(\delta-1)\right)}{X(X+\beta Z)+\beta \eta_{w} w\left(\beta\left[Z^{2}+2(\delta-1)\right]-2(\delta-1)\right)}
$$

where the denominator is positive so that we have

$$
\frac{d w^{N}}{d c}\left\{\begin{array}{l}
> \\
= \\
<
\end{array} 0 \text { as } \beta\left\{\begin{array}{l}
> \\
= \\
<
\end{array}\right\} \frac{2(\delta-1)}{\left(2+(1+\delta) \gamma \frac{M^{*}}{L^{*}}\right)^{2}+2(\delta-1)} \cdot\right. \text { QED }
$$

